\section{Agricultural research pruned}

\section{Heidelberg, Germany}

GERMANy is to make dramatic cuts in agricultural research, an area that was of top priority in the former East Germany, but which holds much less interest to a newly unified country that is putting its resources into high-technology.

If last week's recommendations of the Wissenschaftsrat, Germany's science advisory council, are carried out, up to 50 per cent of the 4,000 scientists and 6,000 technical assistants working at the Academy of Agricultural Research and the research institutions formerly associated with the East German Ministry of Food and Agriculture will lose their jobs by the end of the year.

There is an surfeit in agricultural research because the former East Germany was striving for self-sufficiency, say Werner Kleinhanss and Susanne Reichrath from the Wissenschaftsrat. As the country had little foreign exchange to buy items from the West, it was forced to become self-contained in such areas as the development of scientific instruments and the production of chemicals. Since unification, that motivation has become less important.

The breeding and keeping of livestock and research on animal diseases were also of vital importance in East Germany. This led to the establishment of oversized institutions, such as the institute for research on livestock production at Dummerstorf near Rostock, which had 1,200 employees, including 350 scientists - three times the number at similar institutions in the west.

To set up competitive research for the future, the Wissenshaftsrat council suggests a major shift in emphasis in agricultural research, from self-sufficiency to ecologically oriented research - a move that will lead to severe cuts not only in personnel but also in research facilities. According to the science council, research areas of "outstanding scientific potential"

include animal and plant breeding as well as research on animal diseases and epidemics.

From the 47 institutes evaluated, the science council suggests founding five Blue List establishments (whose funding is shared equally by the Federal government and state in which the institute is located). They will be the first institutes of this kind in agricultural research in the united Germany. It also suggests that two national research laboratories should be founded: one in Jena in the state of Thuringia that will study animal epidemics, and one in Quedlinburg in the Harz for plant breeding. Five other institutes will be privatized, whose areas of expertise include machine building, veterinary medicine and food technology.

The biggest of the Blue List establishments will concentrate on soil research, ecology and environmental problems, especially those due to excessive use of fertilizer. Located at Müncheburg and Eberswalde in Brandenburg, it will employ 300 people (including 100 scientists) out of the 1,000 employees formerly employed there. The 1,200-person Dummerstorf institute will be trimmed to 70 scientists with up to 180 assistants, who will study genetics of livestock, breeding and feeding. The science council also suggests creating an institute in Berlin for Agricultural Development in Middle and Eastern Europe to do research aimed at easing the transition to a market economy.

The recommendations on agricultural research completes the process of reviewing 130 scientific establishments in the former East Germany. The Wissenshaftsrat has recommended creating more than 30 Blue List establishments, three national research laboratories and two Max Planck institutes. In all, a little more than 13,000 jobs will be available for the $30,000 \mathrm{em}^{-}$ ployees of the former East German academics, which will cease to exist at the end of the year.

Barbara Bachtler BRAZI:

\title{
War of the greens
}

\section{Saô Paulo}

JUST months before heads of state from around the world are due to converge on Brazil for the Rio 1992 environmental conference, Brazil's own environmental officials have become embroiled in a blood feud that has already claimed one job.

Tania Munhoz, who headed the Brazilian Institute of the Environment and Natural Renewable Resources, was fired earlier this year because, she said, she was no longer able to work with the explosive national secretary for the environment, José Lutzenberger. Since then, other offi- cials, from the governor of the state of Amazonia to an Army general, have used the dispute as attack both Lutzenberger and Munhoz for compromising on Brazil's right to economic development and sovereignty over the rain forests.

The Brazilian environment, meanwhile, continue to suffer. Last month a team of scientists estimated that some 88,000 fires are burning in Brazil on a peak week, releasing between six and 12 million tons of soot - on the order of a volcanic eruption.

Ricardo Bonalume Neto

\section{Bhopal case near end}

\section{New Delhi}

AfTER nearly seven years of anguish, victims of the Bhopal gas disaster will at last be able to get their share of the $\$ 470$ million that the Indian government received two years ago as compensation from the Union Carbide Corporation of the United States. This follows a Supreme Court verdict last week upholding the compensation settlement reached in February 1989 by Union Carbide and the then-Congress government led by Rajiv Gandhi.

Although Union Carbide had paid the money in March 1989, its disbursal was halted by Gandhi's opponents and citizens' groups who described the deal as a sell-out to the US multinational. The successor National Front government referred the case back to the Supreme Court, in keeping with its election promise to get a better deal for the gas victims, while the money was allowed to lie in a bank gathering interest.

Reviewing the case afresh, four out of five judges of the Supreme Court declared the compensation settlement just and fair and asked the Indian government to make up for any shortfall. One judge dissented.

The majority verdict by the Apex Court has now paved the way for speedy disbursal of the money to nearly 200,000 survivors and families of the 3,800 killed when 40 tons of toxic methyl isocyanate (MIC) gas escaped from Union Carbide's pesticide factory in Bhopal on 2 December 1984. The court also asked Union Carbide to set up a 500-bed hospital in Bhopal and directed the Indian government to provide insurance coverage for unborn children whose mothers were exposed to MIC.

While upholding the compensation settlement, the Supreme Court reversed its 1989 decision granting Union Carbide and its Indian subsidiary immunity from criminal charges. Cases against Union Carbide and its officials pending in various Indian courts - which were quashed in 1989 - can now be reopened. In the original case filed in a Bhopal court, the former Chairman of Union Carbide, Warren Anderson, was charged with homicide. Several officials of the Indian subsidiary also faced criminal charges.

The Supreme Court verdict has generally been welcomed by Indians bar a few activists organizations which expected the court to raise the compensation amount. $A$ spokesman of Union Carbide described as "unfortunate" the decision to allow criminal cases to be reopened. Union Carbide, which maintains that the gas leak was caused by employee sabotage, said that a "fair hearing on this sabotage issue will establish the true cause of the disaster."

With the Union Carbide lawyers insisting that Indian courts have no jurisdiction over the American company, it is not yet clear if the curtain on the Bhopal case has finally come down.

K.S. Jayaraman 